\title{
Cocoa husks: a sustainable resource for alkali production
}

\author{
M. MALIKI ${ }^{1 *}$, I.H. IFIJEN ${ }^{2}$ and S.O. OMOROGBE ${ }^{2}$ \\ ${ }^{l}$ Edo University Iyamho (EUI), Edo State, Nigeria. \\ ${ }^{2}$ Rubber Research Institute Iyanomo (RRII), Benin City, Nigeria. \\ *Correspondents author; E-mail: muniratu.maliki@edouniversity.edu.ng ; Tel: +2348125817458
}

\begin{abstract}
Nigeria has no commercial alkali plant and most of her alkali requirements are imported. Thus the sustainability of using cocoa husks as resource for alkali production was investigated. Cocoa husks collected from three locations in Edo State; $\left(\mathrm{CH}_{1}\right),\left(\mathrm{CH}_{2}\right)$ and $\left(\mathrm{CH}_{3}\right)$ were separately burnt to ashes. Moisture content of ashes ranged from $72.25 \pm 1.92 \%$ to $74.75 \pm 4.11 \%$, dry matter from $25.26 \pm 4.11 \%$ to $27.76 \pm 1.92 \%$, while ash content ranged from $20.29 \pm 3.00 \%$ to $23.01 \pm 3.71 \%$. Alkali was extracted from the ashes by leaching with water at room temperature and $\mathrm{CH}_{1}$ had highest alkaline content $(0.84 \pm 0.01 \mathrm{M})$ while $\mathrm{CH}_{2}$ had the lowest $(0.78 \pm$ $0.02 \mathrm{M}$ ). Conductivity of the extract was $72.45 \pm 0.03 \mathrm{~s} / \mathrm{m}, 71.02 \pm 0.02 \mathrm{~s} / \mathrm{m}$ and $71.64 \pm 0.01 \mathrm{~s} / \mathrm{m}$, while the $\mathrm{pH}$ was $11.655 \pm 0.02 \mathrm{~s} / \mathrm{m}, 11.40 \pm 0.01 \mathrm{~s} / \mathrm{m}$ and $11.42 \pm 0.02 \mathrm{~s} / \mathrm{m}$ respectively for $\mathrm{CH}_{1} \mathrm{CH}_{2}$ and $\mathrm{CH}_{3}$. Metal analysis revealed that they contain appreciable potassium $\left(\mathrm{CH}_{1}=43.54 \%, \mathrm{CH}_{2}=41.15 \%\right.$ and $\left.\mathrm{CH}_{3}=41.67 \%\right)$ and sodium $\left(\mathrm{CH}_{1}=34.78 \%, \mathrm{CH}_{2}=37.55 \%\right.$ and $\left.\mathrm{CH}_{3}=34.86 \%\right)$ ions, thus can be used to generate alkali as alternative to foreign alkali, reduce Nigerian dependence on foreign alkali and providing environmental solution to their disposal problem.
\end{abstract}

(C) 2020 International Formulae Group. All rights reserved.

Keywords: Potassium, sodium, ash extract, wastes

\section{INTRODUCTION}

Cocoa (Theobroma cacao) farming is an important part of the global economy with high potentials for employment generation and poverty alleviation. For example, an estimate of 800,000 farm family are employed by cocoa farming in Ghana alone and also generating about $\$ 2$ billion annually in foreign exchange (Adi- Dako et al., 2016). Cote d'Ivoire Coast makes an average annual production of 1.2 million tones of commercial cocoa (Sahore et al., 2015) while over 200,000 tons is produced annually in Cameron (Mahob et al., 2014). Furthermore, about 185,000 metric tons are produced annually in Nigeria (CAN, 2006).
The crop is grown in tropical areas such as West African, South America, and Central America (Adi- Dako et al., 2016; Noble, 2017). In Nigeria, the crop is grown in the Eastern, Southern and Western parts of the country. The economically useful part of the crop is the fruits (cocoa pods) where the seeds (or beans) are removed, amounting for about $25 \%$ of the total weight of the fruit (Karim et al., 2014). The seed processing, results to the generation of huge amount of cocoa husks (67\% of the pod), amounting for an estimated 10 tons per every ton of dry seeds processed (CamposVegas et al., 2018). As a result of inadequate knowledge about waste treatment and 
managements, these wastes are usually discarded in concentrated heaps around the farm areas to rot, resulting to environmental degradation, soil infertility, foul smelling and disease causing conditions around the farm areas. This can also lead to the spread of botanical diseases (Mansur et al., 2014). These conditions could endanger the lives of inhabitants around the neighborhood. However, concept of wastes as useless materials is rapidly changing to that of a valuable resource (Kwaghe et al., 2011) because of its valuable chemical component with nutritive, energetic and fertilizing properties (Liang-Qiao and $\mathrm{Wu}, 2009$ ) that are usually lost by improper waste management methods.

A proper option to which cocoa husk can be put is in the production of ash derived alkali as alternative to inorganic sodium hydroxide $(\mathrm{NaOH})$ and potassium hydroxide $(\mathrm{KOH})$. This option remains largely unexploited and up till now Nigeria do not have a commercial alkali plant. Therefore, most of her alkali requirements are imported. In 1985, about 26,000 tons of sodium hydroxide and potassium hydroxide were imported (Onyegbado et al., 2002). This amount has increased tremendously as result of increasing population, thereby increasing the pressure on importation of inorganic alkali

However, when properly managed these waste could be used to generate alkali solution as alternative to inorganic alkali. Thereby, adding more value to the crop, promoting the creation of new economic activities associated to cocoa farming, increasing the income levels of cocoa farmers and life in rural areas (Sahore et al., 2015). And above all, the nation dependence on imported alkali will reduce considerable if not halted. Also, in line with the Federal Government of Nigeria call to improve on agricultural waste disposal policies and to as much as possible replace imported raw materials with locally sourced raw materials, makes study - Cocoa husks: a sustainable resource for alkali production even more attractive. Also, studies estimating the mass of hydroxide contained per was of ash extract are lacking. It is on these bases that the study is conducted.

\section{MATERIALS AND METHODS Sample collection}

Cocoa Husks $(\mathrm{CH})$ obtained from three locations; Mr Usman farm in the Nikohole area of Auchi $\left(\mathrm{CH}_{1}\right)$, Mr. Ayoola farm, in Usen $\left(\mathrm{CH}_{2}\right)$ and Papa Kemi farm in Ogbogui $\left(\mathrm{CH}_{3}\right)$ all in Edo state in triplicates between October to December 1999. The samples collected were washed separately with distilled water, drained and weighed. Thereafter, they were sun dried for three days, after which they were dried at $100^{\circ} \mathrm{C}$ in an oven to attain constant weight (FAO, 2006).

\section{Moisture content (MC) and dry matter content (DM) determination}

The determination of the moisture content (MC) of the samples was done using standard methods FAO (2006) with little modification. The dry matter content was also done using standard methods (Adewuyi, 2008).

$$
\begin{aligned}
& \text { Moisture content }(\mathrm{MC})=\frac{\mathrm{MO} \times 100}{\mathrm{M} 1} \\
& \text { Dry matter content }(\mathrm{DM})=\frac{\mathrm{M} 2 \mathrm{X} 100}{\mathrm{M} 1}
\end{aligned}
$$

\section{Ashing and determination of ash content (AC)}

Known weights $\left(\mathrm{M}_{2}\right)$ of the bone dried samples were placed separately in an open combustion pan made from aluminum and heated until it ignited and turned into ashes. While heating, a metallic rod with a wooden handle was used to turn the sample to ensure uniform combustion. The ash obtained was left to cool at room temperature and weighed again $\left(\mathrm{M}_{3}\right)$. The ash content was determined according using standard methods (Radojevic and Bashkin, 2006) with little modification.

$$
\text { Ash content }(\mathrm{AC})=\frac{M 3 \times 100}{M 2}
$$

\section{Extraction of alkali from sample ashes}

$100.00 \mathrm{~g}$ of each ash sample was weighed into a 1 litre capacity beaker and 800 $\mathrm{ml}$ water added and the resulting solution agitated thoroughly. Also, the ash solution was 
left for 72 hours at room temperature in an attempt to maximize the alkaline extraction. Finally, the solution was decanted to obtain the extract.

\section{Determination of the alkaline concentration}

$25 \mathrm{ml}$ of the extract was pipette and titrated against $1.35 \mathrm{M}$ hydrochloric acid solution $(\mathrm{HCl})$, using methyl orange as indicator. The titration was done in triplicate and the average titre was used to calculate the alkali content of the extract, using the expression;

$\mathrm{M}_{1} \mathrm{~V}_{\mathrm{I}}=$ mole ratio

$\mathrm{M}_{2} \mathrm{~V}_{2}$

Mole ratio $=1: 1$

\section{Extract $\mathrm{pH}$ and conductivity determination}

The $\mathrm{pHs}$ of the extracts were determined using the jenway $3020 \mathrm{pH}$ machine. The machine was calibrated using buffer solution of 4 and 9 . The conductivity was determined by using TDS (total dissolve oxygen) meter, Hannah instrument.

\section{Metal analysis of the extract}

The spectrophotometric analysis of the metallic ions present in the extract was determined using an atomic absorption spectrophotometer (AAS), model- sola 969 unicam series. The flame used was acetylene flame.

\section{Estimated masses of $\mathrm{NaOH}$ and $\mathrm{KOH}$ (g) obtained from the ash extract}

The estimated masses $(\mathrm{g})$ of $\mathrm{NaOH}$ and $\mathrm{KOH}$ obtained from the ash extract were calculated, considering that $100.00 \mathrm{~g}$ of each ash was extracted by using $800 \mathrm{ml}$ water by using the mathematical expression:

Estimated mass of hydroxide $(\mathrm{g})=$

$$
\begin{gathered}
\text { Alkali Content }\left(\frac{\mathrm{mol}}{\mathrm{dm} 3}\right) \times \text { Molar mass } \\
\left(\frac{\mathrm{g}}{\mathrm{mole}}\right) \times \% \text { composition of elements } \times \mathrm{dm} 3 \\
\hline
\end{gathered}
$$

\section{RESULTS}

Properties of the ash obtained from the samples

The results obtained from moisture content (MC \%), dry matter content (DM \%) and ash content (AC \%) (Table 1) reveals the values are not significantly different $(\mathrm{p}<$ $0.005)$. The $\mathrm{pH}$ values varied significantly $(\mathrm{p}<$ 0.005) with $\mathrm{CH}_{1}$ having the highest value which was significantly different from $\mathrm{CH}_{2}$ and $\mathrm{CH}_{3}$. The

Alkali content and conductivity values were significantly different with $\mathrm{CH}_{1}$ having the highest value while $\mathrm{CH}_{2}$ had the lowest for both.

Atomic adsorption spectrophotometric analysis of some metals in the alkali extract.

The metal concentration analyzed varied significantly among the samples (Table 2). However, the result indicates that potassium and sodium are the main metallic ions present in the ash extract of all the samples, which is distantly followed by magnesium and calcium. Lead was barely present in $\mathrm{CH}_{2}$ and was the highest value which was significantly different from $\mathrm{CH}_{1}$ and $\mathrm{CH}_{3}$ were lead was not present.

\section{Estimated masses of $\mathrm{NaOH}$ and $\mathrm{KOH}$ from $100 \mathrm{~g}$ ash extract}

Estimates of the masses of $\mathrm{NaOH}$ and $\mathrm{KOH}$ from $100 \mathrm{~g}$ ash extract from samples reveals that $\mathrm{CH}_{1}$ had the highest $\mathrm{NaOH}$ and $\mathrm{KOH}$ content. $\mathrm{CH}_{2}$ had the lowest $\mathrm{KOH}$ content while $\mathrm{CH}_{3}$ had the lowest $\mathrm{NaOH}$ content. Comparing the total mass of $\mathrm{NaOH}$ and $\mathrm{KOH}$ content that could be obtained from the extracts indicates that $\mathrm{CH}_{1}$ had the highest mass of both hydroxides, followed by $\mathrm{CH}_{3}$ while $\mathrm{CH}_{2}$ had the lowest mass. 
Table 1: Moisture content (MC), Dry matter content (DM), ash content (AC) Alkali Content, $\mathrm{pH}$ and Conductivity $(\mathrm{s} / \mathrm{m})$ of samples.

\begin{tabular}{llll}
\hline SAMLPES & $\mathbf{C H}$ & $\mathbf{C H}_{\mathbf{2}}$ & $\mathbf{C H}_{\mathbf{3}}$ \\
\hline Moisture content (MC \%) & $72.25 \pm 1.92^{\mathrm{a}}$ & $74.75 \pm 4.11^{\mathrm{a}}$ & $73.83 \pm 2.14^{\mathrm{a}}$ \\
\hline Dry matter content (DM \%) & $27.76 \pm 1.92^{\mathrm{a}}$ & $25.26 \pm 4.11^{\mathrm{a}}$ & $26.17 \pm 2.14^{\mathrm{a}}$ \\
\hline Ash content (AC \%) & $23.01 \pm 3.71^{\mathrm{a}}$ & $20.29 \pm 3.00^{\mathrm{a}}$ & $22.07 \pm 1.74^{\mathrm{a}}$ \\
\hline Alkali Content/ Molarity $\left(\mathrm{mol} / \mathrm{dm}^{3}\right)$ & $0.84 \pm 0.01^{\mathrm{c}}$ & $0.78 \pm 0.02^{\mathrm{a}}$ & $0.81 \pm 0.01^{\mathrm{b}}$ \\
\hline $\mathrm{pH}$ & $11.65 \pm 0.02^{\mathrm{b}}$ & $11.40 \pm 0.01^{\mathrm{a}}$ & $11.42 \pm 0.02^{\mathrm{a}}$ \\
\hline Conductivity $(\mathrm{s} / \mathrm{m})$ & $72.45 \pm 0.03^{\mathrm{c}}$ & $71.02 \pm 0.02^{\mathrm{a}}$ & $71.64 \pm 0.01^{\mathrm{b}}$ \\
\hline
\end{tabular}

Results are expressed as mean of triplicate determinations. (The superscripts a, b and c represents statistical significance).

Values with the same superscript letters on the same row do not differ significantly at $\mathrm{p}<0.05$

Table 2: Atomic Adsorption Spectrophotometric analysis/Concentration and Percentage Composition of some Metals in the Alkali Extract.

\begin{tabular}{|c|c|c|c|c|c|c|}
\hline Metal & $\begin{array}{l}\text { Conc. of } \mathrm{CH}_{1} \\
\text { ppm (mg/litre) }\end{array}$ & $\begin{array}{l}\mathrm{CH}_{1} \% \\
\text { composition } \\
\text { elements }\end{array}$ & $\begin{array}{l}\text { Conc. of } \mathrm{CH}_{2} \\
\text { ppm (mg/litre) }\end{array}$ & $\begin{array}{l}\mathrm{CH}_{2} \% \\
\text { composition } \\
\text { elements }\end{array}$ & $\begin{array}{l}\text { Conc. of } \mathrm{CH}_{3} \\
\text { ppm (mg/litre) }\end{array}$ & $\begin{array}{l}\mathrm{CH}_{3} \% \\
\text { composition } \\
\text { elements }\end{array}$ \\
\hline $\mathrm{K}^{+}$ & $217.12 \pm 1.00^{\mathrm{a}}$ & 43.54 & $184.37 \pm 0.02^{\mathrm{b}}$ & 41.15 & $202.75 \pm 0.05^{\mathrm{c}}$ & 41.67 \\
\hline $\mathrm{Na}^{+}$ & $168.43 \pm 0.03^{\mathrm{b}}$ & 34.78 & $168.22 \pm 0.11^{a}$ & 37.55 & $169.61 \pm 0.01^{\mathrm{c}}$ & 34.86 \\
\hline $\mathrm{Mg}^{2+}$ & $51.03 \pm 0.05^{b}$ & 10.24 & $42.82 \pm 0.10^{a}$ & 9.56 & $51.77 \pm 0.05^{\mathrm{c}}$ & 10.64 \\
\hline $\mathrm{Ca}^{2+}$ & $33.77 \pm 0.01^{b}$ & 6.77 & $30.15 \pm 0.05^{a}$ & 6.73 & $35.57 \pm 0.01^{c}$ & 7.31 \\
\hline $\mathrm{Cu}^{2+}$ & $21.51 \pm 0.02^{b}$ & 4.31 & $18.34 \pm 0.01^{a}$ & 4.09 & $21.65 \pm 0.01^{\mathrm{c}}$ & 4.45 \\
\hline $\mathrm{Fe}^{3+}$ & $5.11 \pm 0.00^{\mathrm{c}}$ & 1.02 & $2.79 \pm 0.00^{\mathrm{a}}$ & 0.62 & $4.04 \pm 0.01^{b}$ & 0.83 \\
\hline $\mathrm{Zn}^{2+}$ & $1.59 \pm 0.01^{\mathrm{c}}$ & 0.32 & $1.33 \pm 0.00^{b}$ & 0.30 & $1.17 \pm 0.01^{\mathrm{a}}$ & 0.24 \\
\hline $\mathrm{Pb}^{2+}$ & $0.00 \pm 0.01^{\mathrm{a}}$ & 0.00 & $0.02 \pm 0.01^{b}$ & 0.01 & $0.00 \pm 0.00^{\mathrm{a}}$ & 0.00 \\
\hline Total & 498.56 & 100.98 & 479.84 & 100 & 486.56 & 100 \\
\hline
\end{tabular}

Results are expressed as mean of triplicate determinations. (The superscripts a, b and c represents statistical significance). Values with the same superscript letters on the same row do not differ significantly at $\mathrm{p}<0.05$. 


\section{DISCUSSION}

The moisture content (MC), dry matter (DM) and ash content (AC) obtained for all the samples were not statistically different. The MC obtained in this study $\mathrm{CH}_{1}\left(72.25 \pm 1.92^{\mathrm{a}}\right.$ $\%), \mathrm{CH}_{2}\left(74.75 \pm 4.11^{\mathrm{a} \%}\right)$ and $\mathrm{CH}_{3}(73.83 \pm$ $2.14 \%$ a were similar to the $76.00 \pm 2.00 \%$ obtained by (Akindejoye, 2017) but lower than the $80.9-86.7 \%$ obtained by (Babayemi et al., 2010), respectively for cocoa pods and plantain peels in similar studies. The variations in values for plantain peels could be because the crops are different. Ash content was high $(20.29 \pm 3.00 \%-23.01 \pm 3.71 \%)$ compared to $11.62 \pm 3.00 \%$ obtained by (Akindejoye, 2017) for cocoa pods in a similar study. Climatic variations, seed species, and geological locations could be responsible for the deviations. The high ash content for cocoa husks obtained in this study is likely attributed to their high mineral content. The molarities of the ash extracts were $0.84,0.78$ and 0.81 for $\mathrm{CH}_{1}, \mathrm{CH}_{2}$ and $\mathrm{CH}_{3}$ respectively. The molarities of the ash extract were higher than the $0.23 \mathrm{M}$ and $0.45-0.49 \mathrm{M}$ obtained respectively by (Onyegbado et al., 2002) and (Olabanji et al., 2012) using plantain peels ash/banana and plantain peels ash in similar studies. Higher concentrations obtained in this study could be attributed to difference in plants and the use of lower volumes of the extraction solvent and allowing the extraction solution to stand for a longer period (72 hours).

The $\mathrm{pH}$ values of the samples were not considerably different, while conductivity values obtained for $\mathrm{CH}_{1}$ was highest.
Table 2 reveals that the main metallic ions present in the ash extracts were potassium and sodium. Potassium was higher than sodium in all the samples with $\mathrm{CH}_{1}$ containing the highest percentage of potassium ion $(43.54 \%)$ and $\mathrm{CH}_{2}$ recorded the lowest $(41.15 \%)$. The amount of metallic ions content in the extract followed the same trend of $\mathrm{K}>\mathrm{Na}>\mathrm{Mg}>\mathrm{Ca}>\mathrm{Cu}>\mathrm{Fe}$. This observation is consistent with some research findings (Akindejoye et al., 2017; Ayeni, 2010) while (Olabanji et al., 2012) had a different trend.

However, highest total metal content was recorded by $\mathrm{CH}_{1}(498.56 \mathrm{mg} / \mathrm{liter})$ while $\mathrm{CH}_{2}$ (479.84mg/liter) had the lowest. The heavy metal ions under study $(\mathrm{Cu}, \mathrm{Fe}, \mathrm{Zn}$ and $\mathrm{Pb}$ ) constituted less than $6 \%$, with $\mathrm{Pb}$ which is known to course different kinds of adverse environmental and health conditions (Eze et al., 2013) was almost not present in the samples, suggesting that alkali extract from the will not pose any pollution threat.

Figure 1 shows the estimated masses of $\mathrm{NaOH}$ and $\mathrm{KOH}(\mathrm{g})$ obtained from $100 \mathrm{~g}$ ash extract. From the result it is observed that potassium hydroxide was higher in all the samples with the highest hydroxide obtained by $\left(\mathrm{CH}_{1}\right) \cdot \mathrm{CH}_{1}$ also had the highest mass for sodium hydroxide. The highest hydroxides obtained for $\mathrm{CH}_{1}$ could be attributed to the fact that it had the highest ash content, suggesting high mineral content. Previous studies (Ooi, et al., 2012) reported that high ash content was a result of high-value of mineral composition.

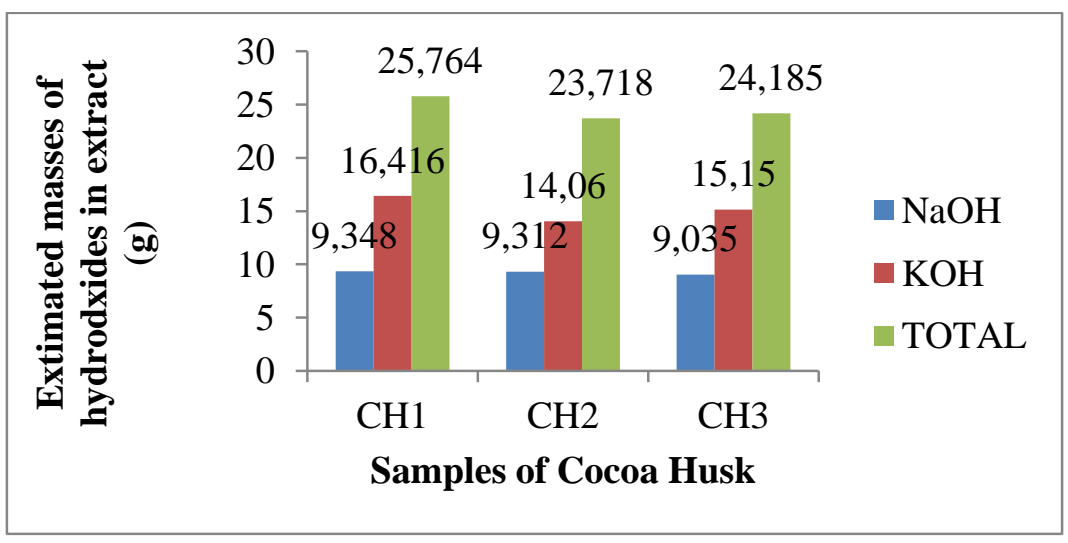

Figure 1: Estimated masses of $\mathrm{NaOH}$ and $\mathrm{KOH}(\mathrm{g})$ from $100 \mathrm{~g}$ ash extract. 


\section{Conclusion}

Results from this study reveal that these agricultural wastes contain appreciable amount of alkali. It estimated that more than $20 \mathrm{~g}$ of alkali hydroxide can be obtained per $100 \mathrm{~g}$ of ash, so when properly harnessed can serve as raw material for different industrial and analytical use. More research in the study, particularly in the area of extract purification would make these agricultural wastes more useful and also cutting down on or eliminating the country's importation requirement for alkali.

\section{COMPETING INTERESTS}

The authors declare that they have no competing interests.

\section{AUTHORS' CONTRIBUTIONS}

MM: Conceptualization methodology, formal analysis, investigation and writing original draft. IHI: conceptualization, supervision and SOO: validation, resources, review and editing.

\section{ACKNOWLEDGMENTS}

The authors appreciate Edo University Iyamho for allowing the analysis to be conducted in their chemistry laboratory.

\section{REFERENCES}

Adewuyi GO, Obi-Egbedi NO, Babayemi, JO 2008. Evaluation of ten different African wood species for potash production. International Journal of Physical Science, 3(3): 63-68.

Adi-Dako O, Ofori-Kwaky K, Manso SF, Boakye-Gyas ME, Sasu C, Pobee M. 2016. Physicochemical and Antimicrobial Properties of Cocoa Pod Husk Pectin Intended as a Versatile Pharmaceutical Excipient and Nutraceutical. Hindawi Publishing Corporation. Journal of Pharmaceutics, 1-12. DOI: http://dx.doi.org/10.1155/2016/7608693 Akindejoye F, Hammed TB, Sridhar MKC. 2017. Potassium Recovery Potential of Selected Agroforestry and Organic
Wastes in Ibadan, Nigeria. European Scientific Journal, 13: 1857 - 7881.

Ayeni LS. 2010. Effect of Cocoa Pod Ash, NPK Fertilizer and their Combinations on Soil Chemical Properties and Yield of Tomato (Lycopersicon lycopersicum) on Two Soil Types. New York Science Journal, 3(4): 1-11.

Babayemi JO, Dauda KT, Kayode AAA. 2010. Assessment of Ancient and Improved alkali Production Technology. Asia Journal of Applied Science, 2: 22 - 29.

Campos-Vega R, Nieto-Figueroaa KH, Oomah BD. 2018. Cocoa (Theobroma cacao L.) pod husk: Renewable source of bioactive compounds. Trends in Food Science \& Technology, 81: 172-184.

CAN. 2006. Cocoa Association of Nigeria.

Eze SO, Igwe JC, Dipo D. 2013. Effect of particle size on adsorption of heavy metals using chemically modified and unmodified fluted pumpkin and broadleafed pumpkin pods. Int. J. Biol. Chem. Sci., $\quad 7(2): \quad 852-860$ http://ajol.info/index.php/ijbcs

FAO. 2006. Food and Agricultural Organisation Production. Production Year book 2004. FAO, Rome.

Liang SW, Qiao W, Wu XL. 2009. Disposal Status and Resource Utilization of Municipal Organic Waste in Shenzhen. Environmental Sanitation Engineering, 17(6): 395-43.

Karim K, Hoffmann R, Klasson KT, AlDahhan MH. 2005. Anaerobic digestion of animal waste: effect of mode of mixing. Water Resources, 39 (15): $3397-$ 3606.

Kwaghe PV, Gwany MM, Abdulsalam PY, Oppong-Yeboah A. 2011. Economic Analysis of Agricultural Waste Management among Farming Households in Jere Local Government of Borno State, Nigeria. Journal of Agriculture and Biological Science, 2(6): $193-198$.

Mahob RJ, Ndoumbè-Nkeng M, Ten Hoopen GM, Dibog L, Nyassé S, Rutherford M, Mbenoun M, Babin R, Amang J, Mbang A, Yede Y, Bilong Bilong CF. 2014. 
Pesticides use in cocoa sector in Cameroon: characterization of supply source, nature of actives ingredients, fashion and reasons for their utilization. Int. J. Biol. Chem. Sci., 8(5): 1976-1989. http://ajol.info/index.php/ijbcs

Mansur D, Tago T, Masuda T, Abimanyu H. 2014. Conversion of cacao pod husks by pyrolysis and catalytic reaction to produce useful chemicals. Biomass and Bioenergy, 66: 275-285.

Noble MD. 2017. Chocolate and the Consumption of Forests: A CrossNational Examination of Ecologically Unequal Exchange in Cocoa Exports. Journal of World-Systems Research, 23(2): $236-268$.

Olabanji IO, Ayodele Oluyemi EA, Ajayi OS. 2012. Metal analyses of ash derived alkalis from banana and plantain peels (Musa spp.) in soap making. African
Journal of Biotechnology, 11(99): 1651216518. DOI: $10.5897 / A J B 12.2255$

Onyegbado CO, Iyagba ET, Offor JO. 2002. Solid soap production using Plantain peel ash as source of alkali. Journal of Applied Science and Environmental Management, 6(1): $73-77$.

Ooi D, Iqbal, S, Ismail M. 2012. Proximate Composition, Nutritional Attributes and Mineral Composition of Peperomia pellucida L. (Ketumpangan Air) Grown in Malaysia. Molecules, 17: 1113911145. DOI: 10.3390/molecules170911139

Radojevic M, Bashkin V. 2006. Plant Analysis. Practical Environmental Analysis (2 ${ }^{\text {nd }}$ edn). Royal Society of Chemistry.

Sahore AD, Afferi JK, Oka L, Abouattier JL, Boua, KB. 2015. Contribution to the Study of the Cocoa Pod Cortex Valorization. Journal of Global Biosciences, 4(8): 3201 - 3206. 